\title{
Two waves of transcription are required for long-term memory in the honeybee
}

\author{
Damien Lefer, ${ }^{1,2}$ Emmanuel Perisse, ${ }^{3}$ Benoît Hourcade, ${ }^{1,2}$ JeanChristophe Sandoz, ${ }^{4}$ \\ and Jean-Marc Devaud ${ }^{1,2,5}$

\begin{abstract}
${ }^{1}$ Université de Toulouse, UPS, Centre de Recherches sur la Cognition Animale, F-31062 Toulouse Cedex 9, France; ${ }^{2}$ CNRS, Centre de Recherches sur la Cognition Animale, F-31062 Toulouse Cedex 9, France; ${ }^{3}$ Centre for Neural Circuits and Behaviour, University of Oxford, Tinsley Building, Mansfield Road, Oxford OX1 3SR, United Kingdom; ${ }^{4}$ Laboratoire Evolution, Génomes et Spéciation (LEGS)_CNRS UPR 9034, Avenue de la Terrasse, 91198 Gif sur Yvette, France
\end{abstract}

\begin{abstract}
Storage of information into long-term memory (LTM) usually requires at least two waves of transcription in many species. However, there is no clear evidence of this phenomenon in insects, which are influential models for memory studies. We measured retention in honeybees after injecting a transcription inhibitor at different times before and after conditioning. We identified two separate time windows during which the transcription blockade impairs memory quantitatively and qualitatively, suggesting the occurrence of an early transcription wave (triggered during conditioning) and a later one (starting several hours after learning). Hence insects, like other species, would require two transcription waves for LTM formation.
\end{abstract}

[Supplemental material is available for this article.]

The formation and maintenance of stable memories of past experience is a common feature of vertebrates and invertebrates. It involves consolidation, i.e., the transition from short-term, labile memory traces to long-term, resistant ones (McGaugh 2000). Consolidation includes several biochemical processes, among which protein synthesis is crucial and now considered as a distinctive hallmark of long-term memories (LTM) in many species (Davis and Squire 1984). Still, based on data from studies on rodents and on Aplysia in particular, a general model of memory consolidation posits that translation of new proteins may come only as a second step, once new transcripts have been produced. Indeed, studies using blockers of transcription rather than of translation have shown that transcription inhibition selectively impairs LTM in a wide range of species (e.g., Neale et al. 1973; Pedreira et al. 1996; Igaz et al. 2002; Lee et al. 2008). It is now widely accepted that consolidation requires transcriptional activation or repression, occurring in at least two separate waves (Bailey et al. 1996; Stork and Welzl 1999; Alberini 2009). First, a limited subset of genes encoding for transcription factors (immediate-early genes) are activated or unrepressed during and/or very shortly after learning (Abraham et al. 1991; Tischmeyer and Grimm 1999, Hawk and Abel 2011). Second, the protein products of these genes modulate the expression of a broader set of target genes several hours later, eventually leading to stable changes in synaptic transmission through protein synthesis (Bailey et al. 1996). Such dynamics based on multiple waves seem to be a rather general property of LTM formation, common to both vertebrates and invertebrates: apart from the former, its existence has been shown in molluscs and crustaceans (Freudenthal and Romano 2000; Lee et al. 2008), but no experimental evidence exists for multiple transcription waves in insects. This is all the more surprising that two insect species, the fruit fly Drosophila melanogaster and the honeybee Apis mellifera, are influential models in the study of memory.

${ }^{5}$ Corresponding author

E-mail jean-marc.devaud@univ-tlse3.fr

Article is online at http://www.learnmem.org/cgi/doi/10.1101/Im.026906.112.
In these two species, as well as in some other insects (Jaffé 1980; Barraco et al. 1981; Matsumoto et al. 2003; Collatz et al. 2006), it was shown that blocking protein synthesis impairs the consolidation of LTM (Tully et al. 1994; Xia et al. 1998; Menzel et al. 2001; Friedrich et al. 2004; Lagasse et al. 2009; for review, see Schwärzel and Müller 2006). However, the extent to which LTM consolidation induces translation of the transcripts already present at the time of learning or de novo transcription followed by translation is not clear. While LTM is characterized by its sensitivity to translation inhibitors in Drosophila, microarray experiments (Dubnau et al. 2003) and genetic manipulations (Chen et al. 2012) have identified genes whose transcription was up- or down-regulated during the first $24 \mathrm{~h}$ after learning, some of which proved to be necessary for consolidation. In the honeybee, only the most stable version of LTM (late LTM [l-LTM]) requires transcription (as opposed to early LTM [e-LTM], for which translation but not transcription is necessary) (Menzel 2001; Menzel et al. 2001; Schwärzel and Müller 2006). Still, the dynamics of memory-associated transcription are not known in these insect species, despite their importance as experimental models for memory studies. Here, we address this question in the honeybee using a pharmacological approach coupled to olfactory conditioning and establish two different time windows for the sensitivity of LTM to transcription blockade.

In the laboratory, harnessed honeybees can be trained in a Pavlovian conditioning procedure to learn and remember an association between an odorant (the conditioned stimulus [CS]) and a sucrose reward (the unconditioned stimulus [US]) in a standard assay, the conditioning of the proboscis extension response (PER) (Bitterman et al. 1983; for review, see Giurfa and Sandoz 2012). The PER is a reflex response elicited by the presentation of sucrose on the antennae, tarsa, or mouthparts. After one or several paired presentations of CS and US, bees can show a conditioned response by extending their proboscises upon stimulation with the CS alone. Manipulations of the parameters of the conditioning procedure, such as the number of trials and the intertrial interval, have shown that multiple (3-5) trials separated by rather long 
(8-10 min) intervals ("spaced conditioning") are conditions suitable for the formation of l-LTM, typically measured 3 or $4 \mathrm{~d}$ later (Sandoz et al. 1995; Wüstenberg et al. 1998; Menzel et al. 2001). In such conditions, blocking gene transcription with actinomycin D (ActD) impairs the expression of this memory when tested 3-d postconditioning. This has been shown in studies using different numbers of trials, intertrial intervals, and times of ActD injection (Wüstenberg et al. 1998; Menzel et al. 2001; Friedrich et al. 2004). Although the fact that ActD blocks l-LTM is well established, there is still uncertainty about when exactly transcription is required and whether it extends over one or two distinguishable waves.

We aimed at determining precise time windows for the dependence of l-LTM on transcription by injecting ActD at different time points before or after spaced conditioning (five trials, $10 \mathrm{~min}$ apart [Supplemental Methods]). In a first experiment aimed at characterizing the rather late transcription wave suggested previously (Wüstenberg et al. 1998), injections were performed $20 \mathrm{~min}$ before or $3 \mathrm{~h}, 6 \mathrm{~h}, 9 \mathrm{~h}$, or $12 \mathrm{~h}$ after conditioning ( $N=410$ bees). Since in other models (Tischmeyer and Grimm 1999; Alberini 2009) immediate-early gene transcription was shown to take place shortly after conditioning, a second experiment consisted in blocking transcription as early as possible during conditioning. Therefore, injections were performed $3 \mathrm{~h}, 2 \mathrm{~h}$, or $1 \mathrm{~h}$ prior to conditioning, as well as $20 \mathrm{~min}$ before and $3 \mathrm{~h}$ after conditioning $(N=438$ bees). These time points were chosen to account for the delay between injection and effective blockade of transcription (Wüstenberg et al. 1998; Menzel et al. 2001 [see below]). The two data sets were analyzed together.

During conditioning, bees learned the CS-US association efficiently, as reflected in Table S1 by a marked increase in conditioned responses to the CS until the fifth trial (repeated-measure ANOVA, trial effect: $\left.F_{(4,3320)}=905.77, P<0.0001\right)$. All groups but one showed very similar acquisition curves. One group injected with ActD $20 \mathrm{~min}$ before conditioning showed slower acquisition (for which we have no explanation), but this was not observed in the replicate experiment. Levels of conditioned responses varied across groups during conditioning (time effect: $F_{(8,3320)}=20.2, P<0.0001$; treatment $\times$ time interaction: $\left.F_{(32,3320)}=6.18, P<0.0001\right)$, but were not affected by treatment $\left(F_{(1,830)}=0.33, P=0.57\right)$. This reflects lower rates of conditioned responses in some of the groups injected after conditioning, independently of the treatment. In any case, for all injection times the groups treated with ActD and PBS had similar levels of conditioned responses by the end of conditioning (Tukey's test, see Table S1). Thus, any effect of ActD on retention could not be attributed to variations in conditioning success. We then compared levels of responses to the CS in a retention test performed $3 \mathrm{~d}$ after conditioning (Fig. 1A). Overall, ActD injection had a significant effect on retention (treatment effect: $F_{(1,830)}=114.13$, $P<0.0001$ ) which depended on the time of injection (time effect: $F_{(8,830)}=5.19, P<0.0001$; treatment $\times$ time interaction: $\left.F_{(8,830)}=3.52, P<0.0001\right)$. Indeed, post-hoc analysis showed that ActD-treated bees responded less to the CS than did PBS-treated bees when injected either between $3 \mathrm{~h}$ and $1 \mathrm{~h}$ before conditioning (Fisher's exact test: $P<0.0001$ in all cases) or between 3 and $6 \mathrm{~h}$ after conditioning $(3 \mathrm{~h}: P=0.0035$ and $P<$ 0.0001 for the two replicates; $6 \mathrm{~h}: P=0.0021)$ but not later $(9 \mathrm{~h}$ and $12 \mathrm{~h}$, respectively $P=0.82$ and $P=0.99$ ). Injections just before conditioning $(20 \mathrm{~min})$ did not produce any significant impairment of retention either $(P=1.0$ and $P=0.65$ for the two replicates), irrespective of the slower acquisition in the group " $-20 \mathrm{~min}(2) . "$ Overall, these results are consistent with previous work that indicated l-LTM impairment when ActD was injected $1 \mathrm{~h}$ or $6 \mathrm{~h}$, but not $24 \mathrm{~h}$, after conditioning (Wüstenberg et al. 1998). Our data suggest that the transcription wave described before and targeted by such treatments does not last more than 8-9 h. In addition, they provide evidence for another, earlier wave of transcription that appears to be distinct from that described previously. Indeed, the systematic lack of effect when injecting ActD 20 min before conditioning suggests that there is no strong requirement for transcription during an intermediate period. 
The data above, like those in previous work (Wüstenberg et al. 1998; Menzel et al. 2001), only assesses the quantitative impact of the transcription blockade on responses to the CS at long term. However, the specificity of conditioned responses can be measured when testing retention by presenting a novel odorant in addition to that used as CS (Hourcade et al. 2009; Perisse et al. 2009). Thus, we can assess the proportions of individual "specific responses," i.e., cases in which a bee responds to the CS only. Unspecific responses (cases in which a bee responds to the novel odorant) may not only reflect the retrieval of the CS-US association, but also nonassociative components (see below); therefore any effect of ActD on such responses may bias our interpretation of its impact on long-term retention of the specific CS-US memory. For this reason, we systematically presented a novel odorant in all retention tests, and now consider the proportions of bees showing CS-specific responses in each group (Fig. 1B). As observed previously, treatment affects levels of CS-specific responses $\left(F_{(1,830)}=41.95, P<0.0001\right)$, but its impact depends on the time of injection (treatment $\times$ time interaction: $F_{(8,830)}=2.39$, $P=0.015)$. Post-hoc analyses reveal again that ActD is efficient during two separate time windows: when injected $1 \mathrm{~h}$ before (Fisher's exact test: $P<0.0001)$ or $3-6 \mathrm{~h}$ after conditioning $(3 \mathrm{~h}$ : $P=0.0069$ and $P=0.0091$ for both replicates; $6 \mathrm{~h}: P<0.0001$ ). By contrast, ActD did not alter CS-specific responses when injected 20 min before conditioning $(P=1.0$ and $P=0.16$ for both replicates) or $9-12 \mathrm{~h}$ after conditioning $(P=0.39$ and $P=0.61$, respectively). However, unlike earlier, when we considered the responses to the CS regardless of their specificity to this odor (Fig. 1A), there was no significant effect for the earliest injections (23 h before conditioning: $P=0.47$ and $P=0.12$, respectively). Thus, considering the individual specificity of responses allows defining a narrower time window for an early transcription wave required for 1-LTM.

Previous studies showed that only l-LTM formed after repeated conditioning trials with long intervals (spaced conditioning) requires transcription in honeybees (Wüstenberg et al. 1998; Menzel et al. 2001; Friedrich et al. 2004). However, residual responses to the CS can be observed 3-4 d after massed conditioning (successive trials separated by short intervals) or even single-trial conditioning (Sandoz et al. 1995; Gerber et al. 1998; Menzel et al. 2001; Perisse et al. 2009). Since these observations were made mostly without controlling for the specificity of such responses (except in Perisse et al. 2009 for single-trial conditioning), whether they reflect specific memory, and whether this is transcription-dependent l-LTM, is unknown. Hence, we compared the specificity of responses obtained $3 \mathrm{~d}$ after conditioning in bees that had undergone either spaced conditioning (three trials, 10-min intervals), massed conditioning (three trials, 1-min intervals), or single-trial conditioning. All the bees had been injected with either ActD or PBS $3 \mathrm{~h}$ after conditioning. As shown in Figure 2, the level of specific responses varied greatly across groups (ANOVA, treatment effect: $F_{(2,365)}=4.20, P=0.041$ ). As expected, in bees undergoing spaced conditioning ActD led to a significant decrease in the level of specific responses, compared to that with PBS (Fischer's exact test: $P=0.0030$ ). By contrast, both single-trial and massed conditioning yielded levels of specific responses that were similarly low, regardless of treatment (Fischer's exact test, single trial: $P=0.502$; massed: $P=0.492$ ). Thus, only spaced trial conditioning induced bona fide, CS-specific 1-LTM at $3 \mathrm{~d}$.

In the first experiment, we showed that the impact of ActD, when injected early ( $3 \mathrm{~h}$ or $2 \mathrm{~h}$ before conditioning), depended on whether all the responses to the CS or only the CS-specific responses were considered. What may be the explanation for this discrepancy? In principle, three main processes may lead to unspecific responses at long term. The first one is generalization, in

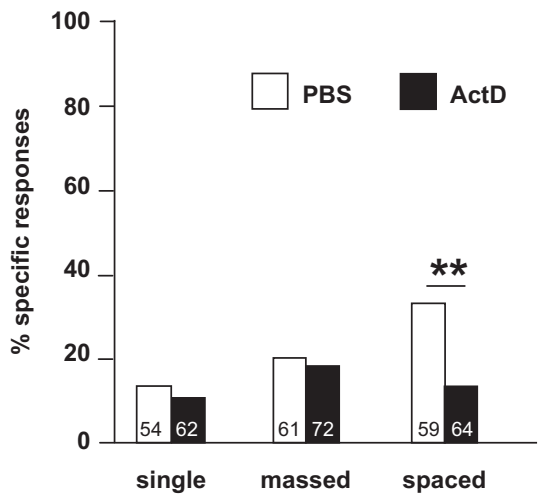

Figure 2. LTM-retention in bees treated with ActD or PBS following different conditioning protocols. Independent groups were subjected to conditioning in one trial (single), three massed trials (massed) or three spaced trials (spaced) and received either PBS or ActD injections. Percentages of individual CS-specific responses in the retention test are provided. Numbers on the bars indicate the sample sizes. $\left(^{* *}\right) P<0.01$ (Fisher's exact test).

which bees that formed the correct CS-US association tend to generalize their response to other odorants perceptually similar to the CS (Guerrieri et al. 2005). Another possibility is the formation of a contextual memory by associating elements of the conditioning setup, present during the whole trial, with the US. Finally, bees may respond to both odorants due to a high level of motivation at the time of the test. These multiple factors and their relative contributions may lead to variable levels of unspecific responses across experiments (see Table S1). First, it should be emphasized that the CS and the novel odorant were chosen based on previous data (Guerrieri et al. 2005), so that they induce only minimal generalization. Reduced discrimination abilities due to ActD injection are also unlikely. Indeed, if the expression of genes involved in olfactory discrimination was impaired, we would have obtained a similar effect at all injection times. Likewise, a specific effect of ActD for the groups injected at -3 and $-2 \mathrm{~h}$ on bees' motivation $3 \mathrm{~d}$ later is unlikely. We should have observed it also in the groups injected shortly thereafter.

We rather favor the idea that contextual or other nonspecific memories, and specific ones, might be affected differentially. Given the estimated time course of ActD action, early injections of ActD are expected to disturb only the beginning of the conditioning period, while injecting later ( $1 \mathrm{~h}$ before conditioning) might impair rather later consolidation events. In addition, we assume that the memories formed during conditioning become more specific as the identification of the CS as the relevant cue (rather than the context) is expected to improve over repeated trials. Thus, our hypothesis would be that the consolidation of specific memories, especially during the last conditioning trials, would be more sensitive to ActD when injected later. Although further experiments are needed to lend more support to this hypothesis, our results stress the importance of considering specific responses when assessing memory retention and its dependency on biochemical pathways.

Our results clearly support the existence of a two-step activation of gene transcription as consolidation of an associative olfactory memory takes place in the honeybee. Earlier studies using similar ActD treatment in honeybees report transcription to be reduced by $60 \%-65 \%$ between $40 \mathrm{~min}$ and up to $2-2.5 \mathrm{~h}$ postinjection (Wüstenberg et al. 1998; Menzel et al. 2001). Based on these estimations, our observations of CS-specific memory impairments allow defining temporal windows for the two transcription waves (Fig. 3). The strong effect of injections $1 \mathrm{~h}$ before 


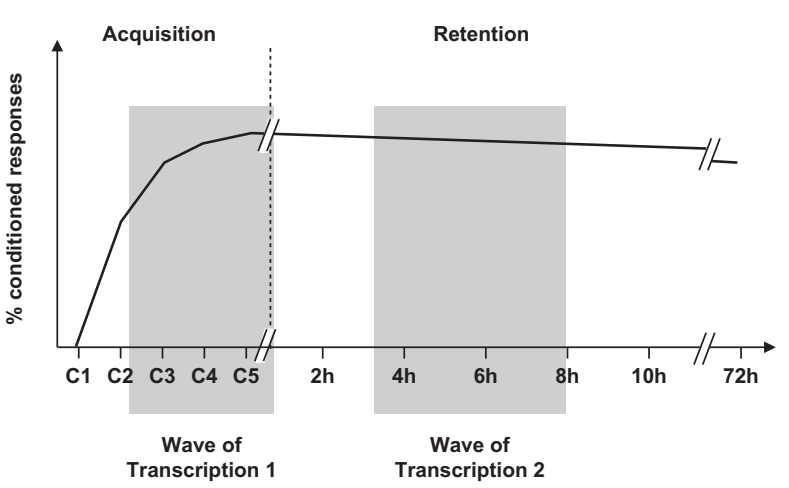

Figure 3. Model of late-LTM consolidation including two transcription waves in the honeybee. Schematic representation of the performance (as measured by the percentage of conditioned responses to the CS) over time, first as acquisition takes place during the five conditioning trials $(\mathrm{C} 1-\mathrm{C} 5)$, and then as retention is allowed by consolidation. Gray rectangles correspond to the estimated periods during which the two transcription waves take place. Note that the time scale is not linear.

conditioning suggests that the first wave would occur during conditioning and would be rather short (not more than $40 \mathrm{~min}$, as injection $20 \mathrm{~min}$ before conditioning did not affect long-term responses). In principle, as supported by our comparison between different conditioning protocols, transcription might be triggered as early as when a second trial takes place, with a sufficient delay after the first trial, i.e., in a spaced conditioning protocol. Accordingly, learning-induced transcriptional regulation was observed within the first hour following learning, particularly for transcription factors, in diverse protocols and species (e.g., Rosen et al. 1998; Malkani and Rosen 2000; Bock et al. 2005; Lee et al. 2008). The second wave induced by spaced conditioning would occur after acquisition is over and would last longer (roughly between 3.5 and $8 \mathrm{~h}$ post-conditioning). It should be noted that these estimates may vary slightly with different conditioning protocols (Zhang et al. 2011). Indeed, a previous study based on another protocol differing in the number of trials (three instead of five) and the intertrial interval duration ( 2 min instead of 10 min) showed that the same dose of ActD impaired 3-day retention (specificity was not assessed) when injected as early as $1 \mathrm{~h}$ after conditioning, but not $6 \mathrm{~h}$ after (Wüstenberg et al. 1998). Although the onset and duration of late transcription events vary across species, they are generally observed several hours after learning (Cavallaro et al. 1997), but in some cases they can span over longer periods (Cavallaro et al. 2002; Donahue et al. 2002; Dubnau et al. 2003). Overall, our results are generally consistent with those proposed for other species with different learning protocols (Rosen et al. 1998; Igaz et al. 2002; Lee et al. 2008).

Altogether, our data suggest that transcription regulation during memory consolidation in the honeybee follows similar dynamics to those previously demonstrated in molluscs and vertebrates. Thus, transcriptomic studies in the honeybee could shed light on the characterization of the different waves of gene expression involved in memory formation.

\section{Acknowledgments}

We thank Liam Cheeseman, Marion Dosnon, and Aurore Hattabi for their assistance in the second experiment, and Sandrine Paute for beekeeping. We also thank the University Paul Sabatier and the CNRS for support. The experiments comply with the "Principles of animal care," Publication No. 86-23, revised 1985, of the National Institutes of Health, and also with the current laws of the country in which the experiments were performed.

\section{References}

Abraham WC, Dragunow M, Tate WP. 1991. The role of immediate early genes in the stabilization of long-term potentiation. Mol Neurobiol 5: 297-314.

Alberini CM. 2009. Transcription factors in long-term memory and synaptic plasticity. Physiol Rev 89: 121-145.

Bailey CH, Bartsch D, Kandel ER. 1996. Toward a molecular definition of long-term memory storage. Proc Natl Acad Sci 93: 13445-13452.

Barraco DA, Lovell KL, Eisenstein EM. 1981. Effects of cycloheximide and puromycin on learning and retention in the cockroach, $P$ americana. Pharmacol Biochem Behav 15: 489-494.

Bitterman ME, Menzel R, Fietz A, Schaefer S. 1983. Classical conditioning of proboscis extension in honeybees. J Comp Physiol A 97: $107-119$.

Bock J, Thode C, Hannemann O, Braun K, Darlison MG. 2005. Early socio-emotional experience induces expression of the immediate-early gene ARC/ARG3.1 (activity-regulated cytoskeleton-associated protein/ activity-regulated gene) in learning-relevant brain regions of the newborn chick. Neuroscience 133: 625-633.

Cavallaro S, Meiri N, Yi C-L, Musco S, Ma W, Goldberg J, Alkon DL. 1997. Late memory-related genes in the hippocampus revealed by RNA fingerprinting. Proc Natl Acad Sci 94: 9669-9673.

Cavallaro S, Dagata V, Alkon DL. 2002. Programs of gene expression during the laying down of memory formation as revealed by DNA microarrays. Neurochem Res 27: 1201-1217.

Chen CC, Wu JK, Lin HW, Pai TP, Fu TF, Wu CL, Tully T, Chiang AS. 2012. Visualizing long-term memory formation in two neurons of the Drosophila brain. Science 335: 678-685.

Collatz J, Müller C, Steidle JL. 2006. Protein synthesis-dependent long-term memory induced by one single associative training trial in the parasitic wasp Lariophagus distinguendus. Learn Mem 13: 263-266.

Davis HP, Squire LR. 1984. Protein synthesis and memory: A review. Psychol Bull 96: 518-559.

Donahue CP, Jensen RV, Ochiishi T, Eisenstein I, Zhao M, Shors T, Kosik KS. 2002. Transcriptional profiling reveals regulated genes in the hippocampus during memory formation. Hippocampus 12: 821-833.

Dubnau J, Chiang AS, Grady L, Barditch J, Gossweiler S, McNeil S, Smith P, Buldoc F, Scott R, Certa U, et al. 2003. The staufen/pumilio pathway is involved in Drosophila long-term memory. Curr Biol 13: 286-296.

Freudenthal R, Romano A. 2000. Participation of Rel/NF-кB transcription factors in long-term memory in the crab Chasmagnathus. Brain Res 855 : $274-281$.

Friedrich A, Thomas U, Müller U. 2004. Learning at different satiation levels reveals parallel functions for the cAMP-protein kinase A cascade in formation of long-term memory. J Neurosci 24: $4460-4468$.

Gerber B, Wüstenberg D, Schütz A, Menzel R. 1998. Temporal determinants of olfactory long-term retention in honeybee classical conditioning: Nonmonotonous effects of the training trial interval. Neurobiol Learn Mem 69: 71-78.

Giurfa M, Sandoz JC. 2012. Invertebrate learning and memory: Fifty years of olfactory conditioning of the proboscis extension response in honeybees. Learn Mem 19: 54-66.

Guerrieri F, Schubert M, Sandoz J-C, Giurfa M. 2005. Perceptual and neural olfactory similarity in honeybees. PLoS Biol 3: e60. doi: 10.1371/ journal.pbio.0030060.

Hawk JD, Abel T. 2011. The role of NR4A transcription factors in memory formation. Brain Res Bull 85: 21-29.

Hourcade B, Perisse E, Devaud J-M, Sandoz JC. 2009. Long-term memory shapes the primary olfactory centre of an insect brain. Learn Mem 16: 607-615.

Igaz LM, Vianna MR, Medina JH, Izquierdo I. 2002. Two time periods of hippocampal mRNA synthesis are required for memory consolidation of fear-motivated learning. J Neurosci 22: 6781-6789.

Jaffé K. 1980. Effect of cycloheximide on protein synthesis and memory in praying mantis. Physiol Behav 25: 367-371.

Lagasse F, Devaud J-M, Mery F. 2009. A switch from cycloheximideresistant consolidated memory to cycloheximide-sensitive reconsolidation and extinction in Drosophila. J Neurosci 29: $2225-2230$.

Lee YS, Bailey CH, Kandel ER, Kaang BK. 2008. Transcriptional regulation of long-term memory in the marine snail Aplysia. Mol Brain 17: 1-3.

Malkani S, Rosen JB. 2000. Induction of NGFI-B mRNA following contextual fear conditioning and its blockade by diazepam. Mol Brain Res 80: $153-165$.

Matsumoto Y, Noji S, Mizunami M. 2003. Time course of protein synthesis-dependent phase of olfactory memory in the cricket Gryllus bimaculatus. Zoolog Sci 20: 409-416. 
McGaugh JL. 2000. Memory-a century of consolidation. Science 287: 248-251.

Menzel R. 2001. Searching for the memory trace in a mini-brain, the honeybee. Learn Mem 8: 53-62.

Menzel R, Manz G, Greggers U. 2001. Massed and spaced learning in honeybees: The role of CS, US, the intertrial interval, and the test interval. Learn Mem 8: 198-208.

Neale JH, Klinger PD, Agranoff BW. 1973. Camptothecin blocks memory of conditioned avoidance in the goldfish. Science 179: 1243-1246.

Pedreira ME, Dimant B, Maldonado H. 1996. Inhibitors of protein and RNA synthesis block context memory and long-term habituation in the crab Chasmagnathus. Pharmacol Biochem Behav 54: 611-617.

Perisse E, Raymond-Delpech V, Neant I, Matsumoto Y, Leclerc C, Moreau M, Sandoz JC. 2009. Early calcium increase triggers the formation of olfactory long-term memory in honeybees. BMC Biol 7: 30 .

Rosen JB, Fanselow MS, Young SL, Sitcoske M, Maren S. 1998. Immediate-early gene expression in the amygdala following foot-shock stress and contextual fear conditioning. Brain Res 796: 132-142.

Sandoz JC, Roger B, Pham-Delègue MH. 1995. Olfactory learning and memory in the honeybee: Comparison of different classical conditioning procedures of the proboscis extension response. $C R$ Acad Sci III 318: 749-755.
Schwärzel M, Müller U. 2006. Dynamic memory networks: Dissecting molecular mechanisms underlying associative memory in the temporal domain. Cell Mol Life Sci 63: 989-998.

Stork O, Welzl H. 1999. Memory formation and the regulation of gene expression. Cell Mol Life Sci 55: 575-592.

Tischmeyer W, Grimm R. 1999. Activation of immediate early genes and memory formation. Cell Mol Life Sci 55: 564-574.

Tully T, Preat T, Boynton SC, Del Vecchio M. 1994. Genetic dissection of consolidated memory in Drosophila. Cell 79: $35-47$.

Wüstenberg D, Gerber B, Menzel R. 1998. Short communication: Long- but not medium-term retention of olfactory memories in honeybees is impaired by actinomycin D and anisomycin. Eur J Neurosci 10: $2742-2745$.

Xia SZ, Feng CH, Guo AK. 1998. Multiple-phase model of memory consolidation confirmed by behavioral and pharmacological analyses of operant conditioning in Drosophila. Pharmacol Biochem Behav 60: 809-816.

Zhang Y, Liu RY, Heberton GA, Smolen P, Baxter DA, Cleary LJ, Byrne JH. 2011. Computational design of enhanced learning protocols. Nat Neurosci 15: 294-297.

Received May 6, 2012; accepted in revised form October 24, 2012. 


\section{Erratum}

Learning \& Memory 20: 29-33 (2013)

Two waves of transcription are required for long-term memory in the honeybee

Damien Lefer, Emmanuel Perisse, Benoît Hourcade, Jean-Christophe Sandoz, and Jean-Marc Devaud

Co-author Jean-Christophe Sandoz's first name was inadvertently missing a hyphen. The correct presentation is noted both here and in the author line above. 


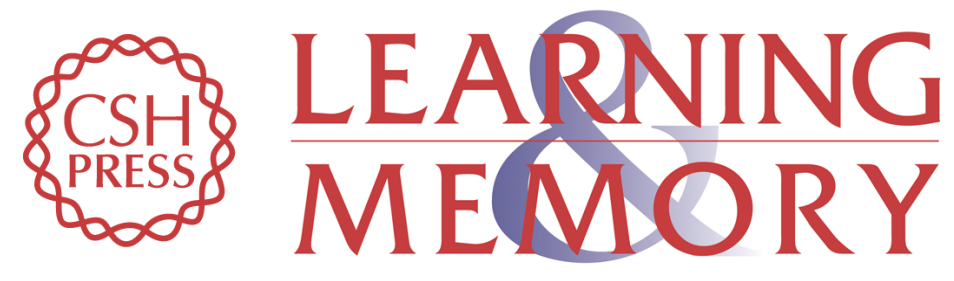

\section{Two waves of transcription are required for long-term memory in the honeybee}

Damien Lefer, Emmanuel Perisse, Benoît Hourcade, et al.

Learn. Mem. 2013, 20:

Access the most recent version at doi:10.1101/Im.026906.112

\section{Supplemental http://learnmem.cshlp.org/content/suppl/2012/12/17/20.1.29.DC1 Material}

Related Content

Erratum

Learn. Mem. May , 2013 20: 289

References This article cites 41 articles, 13 of which can be accessed free at:

http://learnmem.cshlp.org/content/20/1/29.full.html\#ref-list-1

Articles cited in:

http://learnmem.cshlp.org/content/20/1/29.full.html\#related-urls

\section{License}
Email Alerting Receive free email alerts when new articles cite this article - sign up in the box at the Service top right corner of the article or click here.

